\title{
Glaciations in the Khumbu Himal (2)*
}

\author{
Hiroji Fushimi**
}

\begin{abstract}
Geological, topographic and climatic conditions are fundamental in causing the glacial phenomena, and their characteristics and their relationships are discussed.

Observations on glaciations were carried out in the Khumbu, Hinku and Hongu regions, east Nepal, from September to October, 1976.

Glaciations in the Nepal Himalayas are discussed, and two stages of the past glacier advance were dated to be 8 th and 16 th centuries by ${ }^{14} \mathrm{C}$ analyses.
\end{abstract}

\section{Introduction}

The Great Himalayas started to rise in the midTertiary (Miocene about 14 millions years ago) (Ohta et al. 1973) and are considered to be still rising and a great barrier for geology, topography, climate and many forms of life in Central Asia. The Great Himalayas are thought to be the most rapidly changing land in the world.

It is important to understand the geological conditions which cause topographic changes such as the upheavals of the Great Himalayas, Tibetan plateau and other mountain chains in Central Asia. The topographic changes influence the local climatic conditions in relation to the world-wide climatic changes. Topographic as well as climatic conditions are thought to be fundamental for glacial phenomena, and it is important to find out the relationships among geological, topographic and climatic conditions through the history of glaciers.

The past U-shaped valleys are classified into three series: U-1, U-2 and U-3. Periche and Thuklha stages are included in the U-3 series, and the Thuklha stage is subdivided into 6 substages; the present substage is T-6 and the first one T-1 (Fushimi, 1977) (Tab. 2). It is also important to date the stages when glaciers advanced.

In this paper, the characteristics of geology, topography and climate are described in relation to glaciations from results of the observations carried out in the Khumbu, Hinku and Hongu

* Glaciological Expedition of Nepal, Contribution No. 57

** Water Research Institute, Nagoya University, Chikusa-ku, Nagoya, 464.

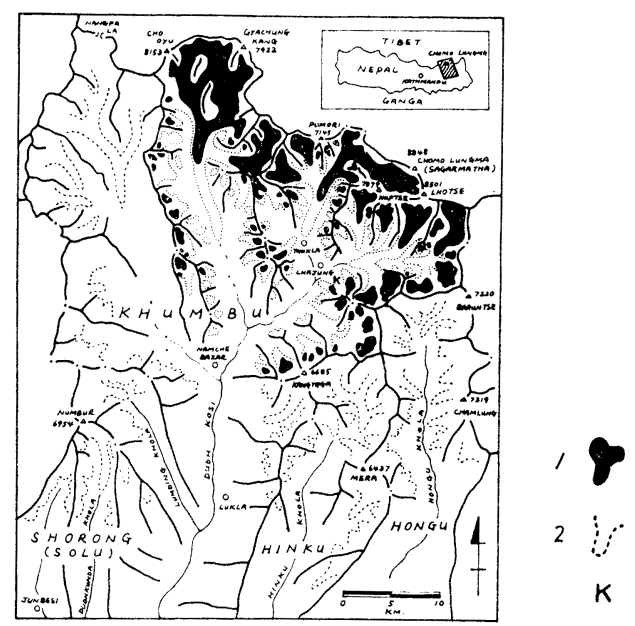

Fig. 1. Index map of the Khumbu, Hinku and Hongu regions, east Nepal and map of glacier distribution at the present T-6 substage (1) and the $T-1$ substage in the Thuklha stage (2). The letter $\mathrm{K}$ indicates the sampling place of the ${ }^{14} \mathrm{C}$ analyses near the Kyuwo Glacier.

regions in east Nepal from September to October, 1976 (Fig. 1). Maps used in this paper are mainly based on "Khumbu Himal" (Schneider et al., 1967) and "Shorong and Hinku" (Schneider et al., 1974).

\section{Geological and topographic characteristics}

Geological structures have a fundamental influence on formation of the topography. The Great Himalayas are thought to be an asymmetrical ridge with gently dipping north slopes and with steep cliffs in the south. The main fault systems run in the N-S and E-W directions. The valley 


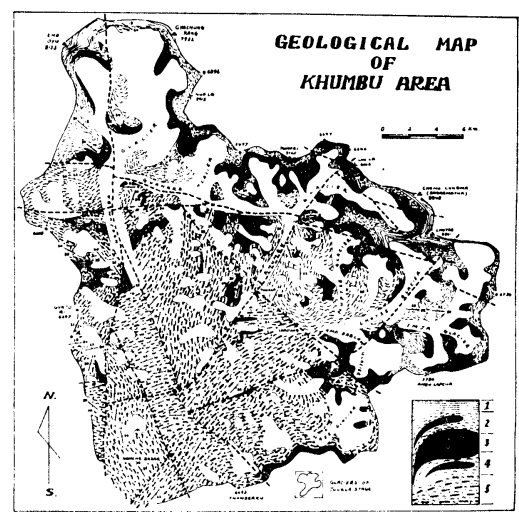

Fig. 2. Geological map of the Khumbu area.

1) Sediments of the Tethys formation,

2) Gneissose rocks, 3) Intrusive granites,

4) Migmatites and gneissose rocks and

5) Migmatites. Fault systems are shown by dotted lines.

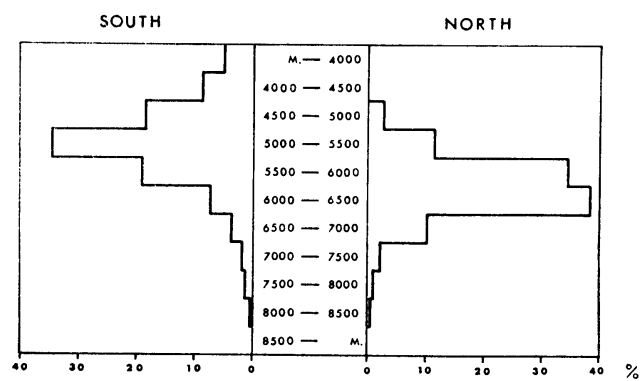

Fig. 3. Area histogram measured at every $500 \mathrm{~m}$ in elevation in the south and in the north of the Great Himalayas by using Schneider's map of the Khumbu Himal.
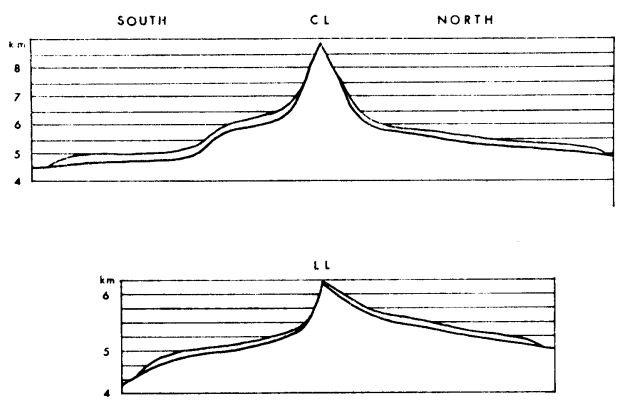
$20 \mathrm{~km}$

Fig. 4. Cross section of the topography and glacier along the Khumbu Glacier in the south and the Rongbuk Glacier in the north. CL stands for Mt. Chomo Lungma (Sagarmatha or Everest) and LL for Lho La. systems and the asymmetrical ridge have the same tendency as the fault systems. Glaciers in the Khumbu, Hinku and Hongu regions flow down in the N-S and E-W directions along the valley systems mainly caused by the fault systems (Fig. 2).

A flat surface exists between $5000-5500 \mathrm{~m}$ on the south side of the Great Himalayas, while it occurs between $5500-6500 \mathrm{~m}$ on the north side (Fig. 3). Figure 4 shows $\mathrm{N}-\mathrm{S}$ sections of the topography around Mt. Chomo Lungma (Sagarmatha or Everest). There is a well-developed ice fall and a steep cliff on the south side of the Great Himalayas.

A flat topography is well developed around Luklha. This region has its own characteristic geology and topography, as a foreland of the Great Himalayas. That is to say, there lies the Main Central Thrust (M.C.T.) on the south side of this region, and a remarkably deep V-shaped valley is observed from Khari Khola in the south to Luklha. The V-shaped valley is thought to be caused by fluvial erosions and upward movements of the M.C.T. related to the upheavals of the Great Himalayas.

A V-shaped valley is also seen along the Hongu Khola on the north of the M.C.T., and the profile of an inclination of the U-shaped valley, $\mathrm{V}$-shaped valley and the present river bed are shown in Fig. 5. The older the U-shaped valley is, the larger the height difference between the river bed and the bottom of the U-shaped valley, and the oldest U-shaped valley (U-1 series) is more uplifted downstream near the M.C.T., so the terminal position stays higher than the middle part of the $\mathrm{U}$-shaped valley.

The topographic changes of the Great Himalayas are so fast that the upheaval rate is a fundamental parameter for understanding the glacial phenomena

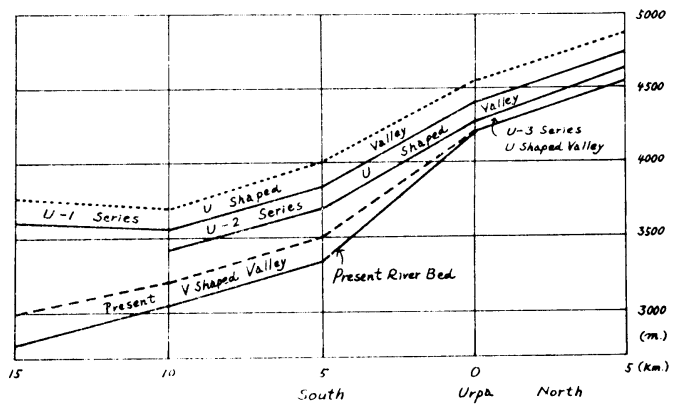

Fig. 5. Longitudinal profile of the past U-shaped valley near Urpa in the Hongu region. 
as well as the nature of the Great Himalayas. There are several observations that show topographic changes such as lake sediments tilted and moraines faulted. There are, near Luklha, preserved the end moraines of the maximum glacier expansion at the Luklha stage of the U-1 series which are partly cemented and sheared by the steep N-S fault, and the lake sediments of the U-2 series (Ghat stage) observed near Ghat are tilted toward the east by local block movements caused by the E-W and the N-S fault systems. The Luklha region is located between the U-shaped valley in the north and the V-shaped valley in the south.

Huge quantities of angular boulders with a fine matrix cover the older moraine surfaces and form a vast flat surface where the Luklha village is situated (Fig. 6). The distribution of this sediments

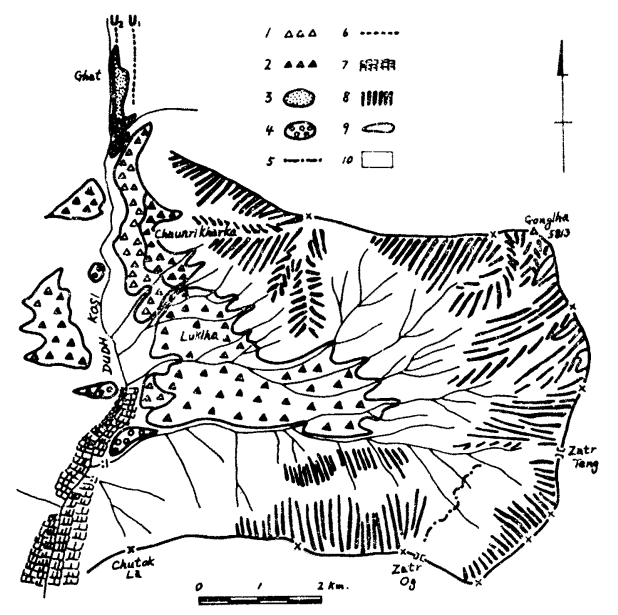

Fig. 6. Geomorphological map near Luklha. 1) Moraine of the U-1 series, 2) Sediments of glacial as well as fluvial origin, 3) Lake sediments, 4) River terrace surface, 5) Moraine of the T-1 substage, 6) Bottom of the U-shaped valley of the U-1 and U-2 series,

7) Valley wall of the V-shaped valley, 8) Rock wall, 9) Glacier and 10) Gentle slope with vegetation.

partly resembles that of a fan and partly that of a land slide, and the matrix is partly composed of fine grey clays which are thought to be glacier clays. The sediments are thought to be of glacial as well as fluvial origin.

\section{Climatic conditions in relation to topographic characteristics}

In the region of the Hinku and Hongu Khola,

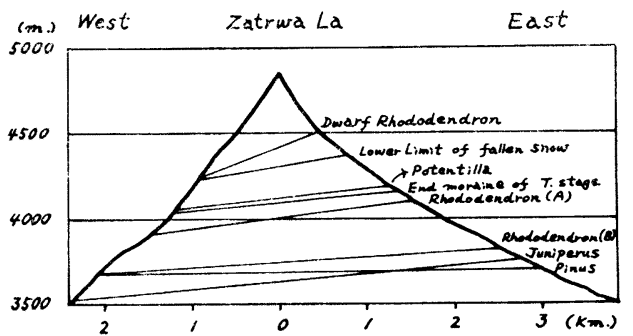

Fig. 7. Altitudinal difference of vegetation, snow line of Oct. 4th, 1976 and end moraine (T-1 substage) between the west-facing and the east-facing slopes of the Zatrwa La. Rhododendron (A) is locally called "Karma" with smaller leaves, while rhododendron (B) is called "Chimar" with larger leaves and straight branches.

the gneissose and migmatitic rocks are well developed. The strike runs along the NW-SE direction and its dip has a NE direction, and this geological structure produces topographic characteristics showing asymmetrical ridges with the steep cliffs being formed on the SW side and the gentle slopes on the NE side. The climatic conditions can be estimated from the upper limits of various vegetations, and the altitude of the temporary snow line and the past end moraine ( $\mathrm{T}-1$ substage). Differences are observed between the east and west facing slopes of the Zatrwa La, a divide between the Dudh Kosi and the Hinku Khola (Fig. 7). The upper limits of all of the vegetations (Dwarf Rhododendron, Potentilla, Rhododendron A, Rhododendron B, Juniperus and Pinus) are lower at an average height difference of $195 \mathrm{~m}$ on the westfacing slope. Similar characteristics are seen at the altitude of the past end moraine and the snow line of October 4, 1976, which are an average of $140 \mathrm{~m}$ lower on the same west slope (Fig. 7). These differences indicate that the west-facing slope has the colder climatic conditions.

\section{Glaciations}

\subsection{Glacier fluctuations in the recent stage}

In relation to the topographic characteristics, the region of Mt. Mera-Mt. Naulekh is chosen to clarify the difference of glacier fluctuations between the west-facing and the east-facing slopes, and the area of the Hongu Nup Glacier (Glacier HX220) to understand the same difference between the north-facing and the south-facing slopes (Fig. 8).

On the east side of the Mt. Mera-Mt. Naulekh 


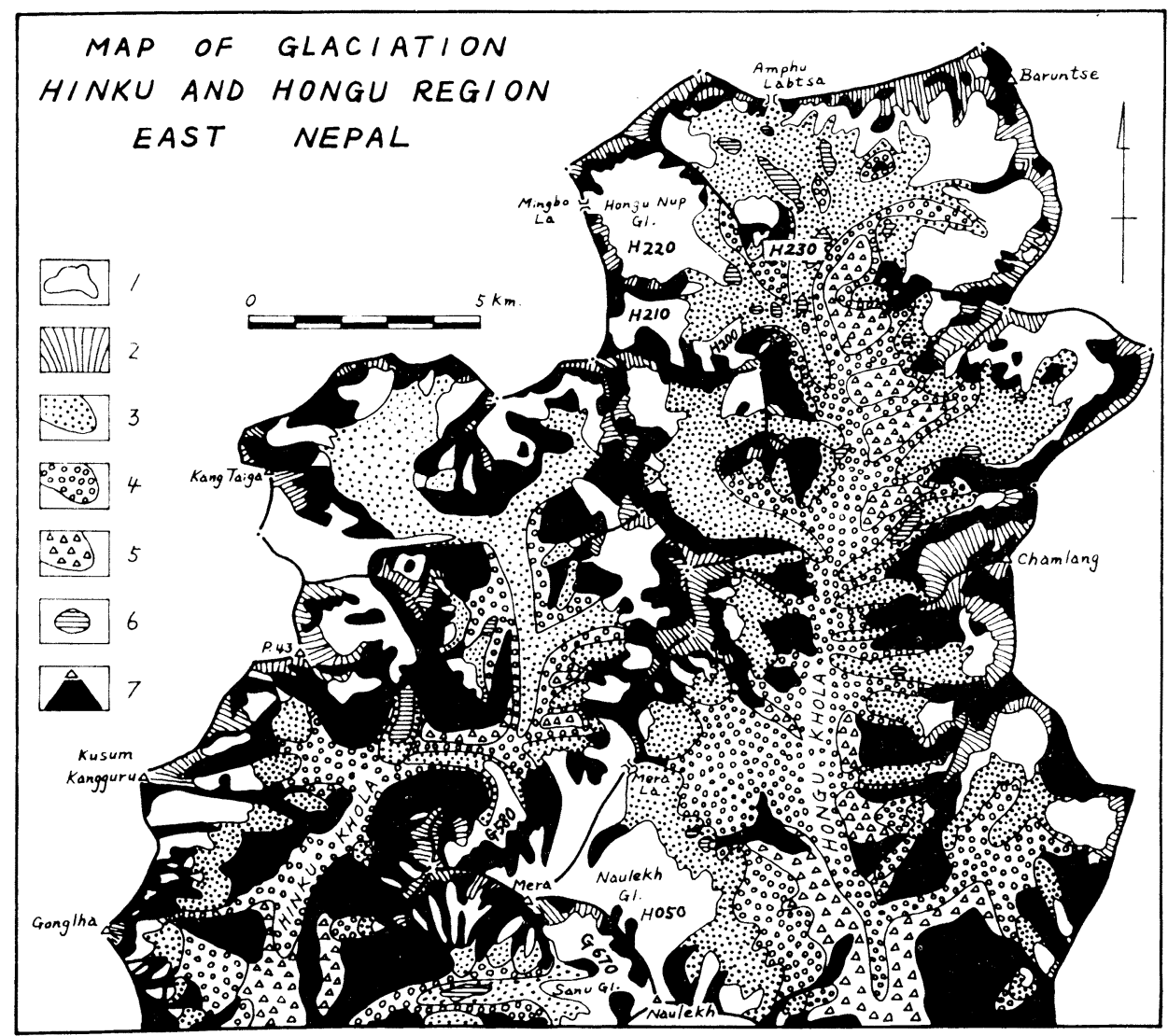

Fig. 8. Map of glaciations in the Hinku and Hongu regions.

1) Present glacier (T-6 substage), 2) Snow cover, 3) Moraine of T-1 substage, 4) Moraine of the Periche stage, 5) Older Moraines of the U-1 and U-2 series, 6) Lake and 7) Peak and rock wall.

region, the area of the present Glacier HX 050 (Naulekh Glacier) decreased to $54 \%$ of that of the past glaciers in the $\mathrm{T}-1$ substage, while the present glaciers on the west side (Sanu Glacier (Glacier GX 670), Dig Glacier (Glacier GX 580) and others) became much smaller, $32 \%$ of the past expansion in the $\mathrm{T}-1$ substage.

In the north-facing slope near the Hongu Nup Glacier, the area of the present Glacier HX 200 is $42 \%$ of the past advance in the T-1 substage, while the south-facing Glacier HX 230 markedly retreated to $15 \%$ of the past glacier area in the T-1 substage. The above-mentioned results on the glacier fluctuations in the Thuklha stage indicate that glaciers on the south- and west-facing slopes became clearly smallre in the recent stage than the glaciers on the north- and east-facing slopes. As there are, on the south- and west-facing slopes, well-developed steep cliffs possibly caused by faulting, the production of the rock materials is high due to the fault movements and active mass movements, and the glacier is composed of immense quantities of rock materials to be having the characteristics of a rock glacier. On the contrary, glaciers in the north- and east-facing slopes stay on the gentle slope with minor activities of faulting, and the glaciers do not have much debris under conditions in which a large area is covered by glaciers so that the mass movements are suppressed.

\subsection{Glaciation in the Khumbu, Hinku and Hongu regions}

Glaciations in the Khumbu, Hinku and Hongu regions are divided into three series (U-1, U-2 and U-3) by the topographic characteristics of the U-shaped valleys and end moraines (Fushimi, 1977).

Two samples of the ${ }^{14} \mathrm{C}$ analyses were collected 
from the bottom of the moraines at the oldest Thuklha stage and Periche stage near the Kyuwo Glacier to the south-east of Lhajung (Fig. 1). The ages of the samples are thought to show the time when the glacier advanced and formed the

Table 1. Area of the present glaciers, snow cover, rock walls, moraines and lakes in the Hinku and Hongu regions. Numbers in parentheses show the percentage of the total area of the valley.

\begin{tabular}{l|c|c} 
& HINKU & \multicolumn{1}{|c}{ HONGU } \\
\hline GLACIERS & $30 \mathrm{Km}^{2}(22 \%)$ & $42 \mathrm{Km}^{2}(20 \%)$ \\
SNOW COVERS & $10 \mathrm{Km}^{2}(7 \%)$ & $16 \mathrm{Km}^{2}(8 \%)$ \\
ROCK WALLS & $49 \mathrm{Km}^{2}(36 \%)$ & $46 \mathrm{Km}^{2}(22 \%)$ \\
MORAINES & $46 \mathrm{Km}^{2}(34 \%)$ & $103 \mathrm{Km}^{2}(49 \%)$ \\
LAKES & $1 \mathrm{Km}^{2}(1 \%)$ & $2 \mathrm{Km}^{2}(1 \%)$ \\
\hline
\end{tabular}

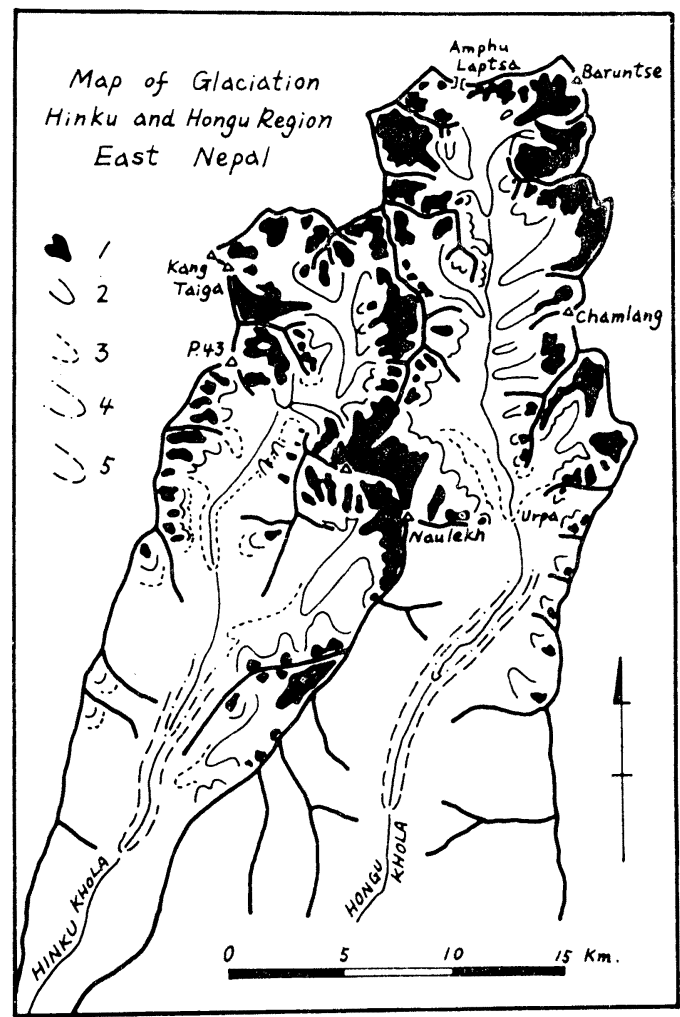

Fig. 9. Map of glaciations in the Hinku and Hongu regions.

1) T-6 substage of the Thuklha stage (present glacier), 2) T-1 substage of the Thuklha stage, 3) Periche stage, 4) U-2 series and 5) U-1 series. moraines. The sample of the Thuklha stage is a wood and that of the Periche stage is a charcoal. Since the ${ }^{14} \mathrm{C}$ age of the former sample is $410 \pm 110$ yr. B.P. (Code No. Gak-6807) and that of the latter is $1200 \pm 100$ yr. B.P. (Code No. Gak-6808), the age of the oldest Thuklha stage (T-1 substage) is thought to be 16 th century and that of the Periche stage 8th century.

In the upper parts of the Hinku and Hongu regions, the moraine cover has the area of $46 \mathrm{~km}^{2}$ (34\% of the total area) in the former valley and $103 \mathrm{~km}^{2}(49 \%)$ in the latter, while the area of the rock walls is $49 \mathrm{~km}^{2}$ (36\% of the total) in the Hinku Khola and $46 \mathrm{~km}^{2}(22 \%)$ in the Hongu Khola. Glaciers in the Hinku region occupy an area of $30 \mathrm{~km}^{2}(22 \%$ of the total) and that in the Hongu region an area of $42 \mathrm{~km}^{2}(20 \%)$ (Table 1 and Fig. 8). These differences show that the moraine cover is widely developed in the Hongu region with a smaller ratio of the area of rock walls and present glaciers to the total area of the valley.

The areal changes of the glacier distributions are shown in Fig. 9 and 10, and the total area of the glaciers at each stage in Table 2. At the maximum expansion, which is correlated to the Luklha stage in the upper part of the Dudh Kosi (Fushimi, 1977), most of the mountains below $6000 \mathrm{~m}$ were covered by glaciers and some of the mountains are thought to have formed a "Nunataks". The total

Table 2. Glacier area of each series, stage and substage in the Khumbu, and in the HinkuHongu regions. Numbers in parentheses show the ratio of the glacier area at each stage to that of the T-6 present substage. The T-6 substage is correlated with Müller's "Recent moraine" (1959) and with Iwata's "Lobuche stage" (1976). The Thuklha stage is also classified by them, but the stages of Ghat and Luklha in relation to the $U-1$ and $U-2$ series are not classified by them except Iwata's "Platform topography". However,Iwata's Thyangboche stage has not been reported by Müller and this author.

\begin{tabular}{|c|c|c|c|c|}
\hline Series & Stage & Substage & $\begin{array}{l}\text { Khumbu } \\
\text { Region }\end{array}$ & $\begin{array}{l}\text { Hinku and } \\
\text { Hongu Regions }\end{array}$ \\
\hline \multirow{3}{*}{ U-3 } & \multirow{2}{*}{ Thuklha } & T-6 & $170 \mathrm{Km}^{2}(1)$ & $72 \mathrm{Km}^{2}(1)$ \\
\hline & & $\mathrm{T}-1$ & $274 \mathrm{Km}^{2}(1.6)$ & $208 \mathrm{Km}^{2}(2.9)$ \\
\hline & Periche & & $481 \mathrm{Km}^{2}(2.8)$ & $288 \mathrm{Km}^{2}(4.0)$ \\
\hline $\mathrm{U}-2$ & Ghat & & $564 \mathrm{Km}^{2}(3.3)$ & $352 \mathrm{Km}^{1}(4.9)$ \\
\hline$U-1$ & Luglha & & $649 \mathrm{Km}^{2}(3.8)$ & $408 \mathrm{Km}^{2}(5.7)$ \\
\hline
\end{tabular}




\section{U-3 Series}
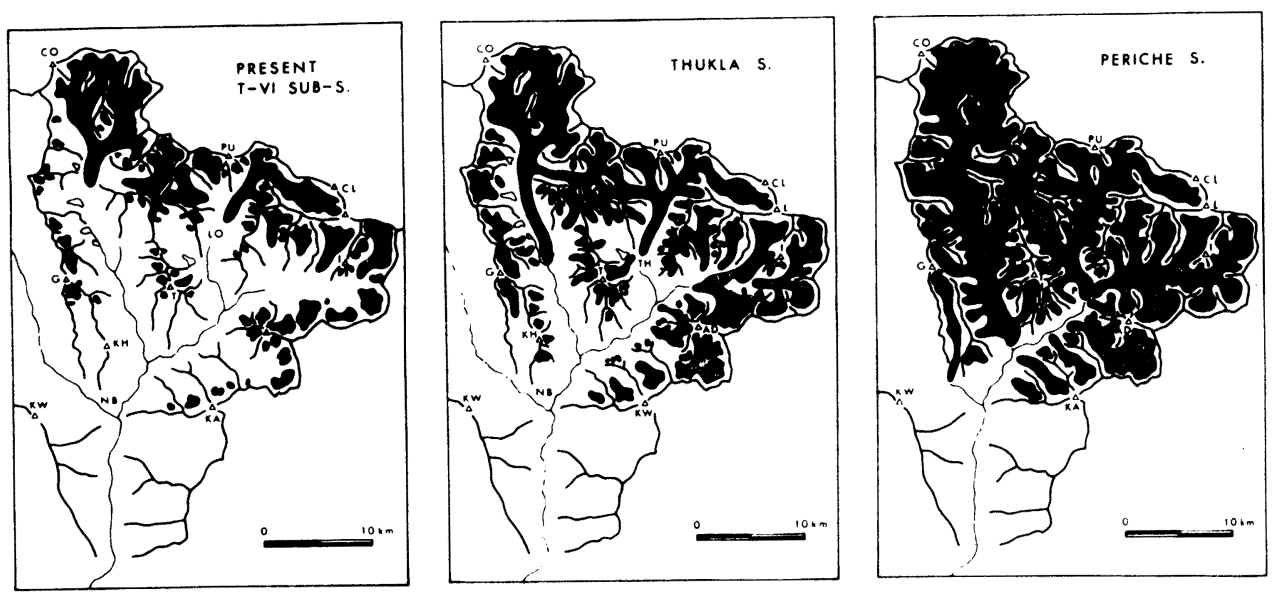

\section{U-2 Series}

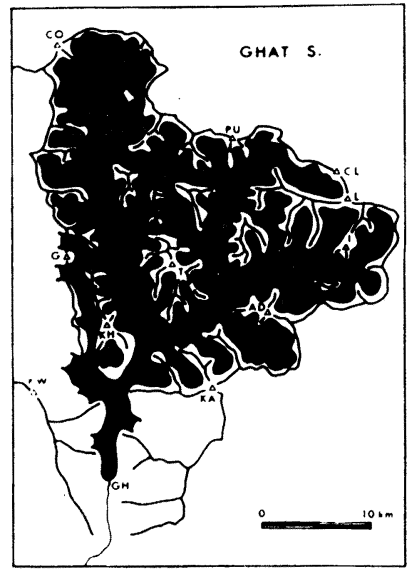

\section{U-1 Series}

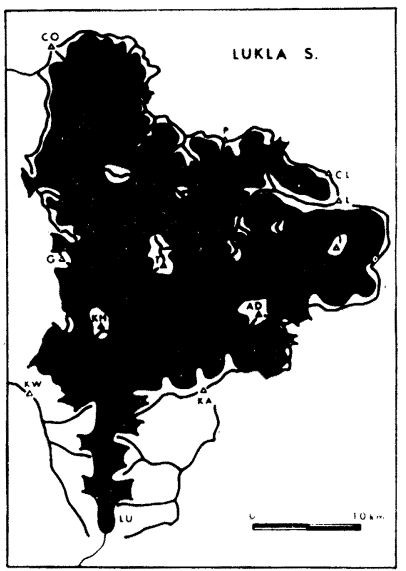

Fig. 10. Map of glacier distribution at each stage in the Khumbu region. From upper left to right, the present substage (T-6), T-1 substage of the Thuklha stage and Periche stage in U-3 Series are shown. From lower left to right, the Ghat stage (U-2 Series) and Luklha stage (U-1 Series) are shown.

LU (Luklha), GH (Ghat), NB (Namche Bazar), P(Periche), TH (Thuklha), LO (Lobuche), CL (Chomo Lungma, Sagarmatha), PU (Pumo Ri), CO (Cho Oyu), G (Gyajo), KW (Kwande), KH (Khumbila), T (Taweche), KA (Kangtega), AD (Ama Dablam), and I (Island Peak).

area of the present glaciers is $72 \mathrm{~km}^{2}$ in the Hinku and Hongu regions, and $170 \mathrm{~km}^{2}$ in the Khumbu region, or about $1 / 6$ of the maximum expansion in the former and about $1 / 4$ in the latter region (Table 2), so it can be said that the areal change of the glaciers is markedly decreasing from the oldest to the recent stage in the Hinku and Hongu regions as compared to that in the Khumbu region. Though the volume of the recent and the past glaciers has not been calculated yet, this region of the Great Himalayas was covered by large quantities of glacier ice at the maximum expansion when the average altitude of this region is thought to have been lower than the present elevation. 


\section{Conclusion}

Observations on glaciations were carried out in the Khumbu, Hinku and Hongu regions, east Nepal, and the following results were obtained.

1) The Great Himalayas are an asymmetrical ridge with gently dipping north slope and with steep cliffs in the south. A flat surface exists between $5000-5500 \mathrm{~m}$ in the south, but between $5500-6500$ $m$ in the north of the Great Himalayas. 2) The original down-stream of the U-shaped valley near the Main Central Thrust has been uplifted to become higher than the mid-stream of the U-shaped valley by thrust movements. 3) Glacial as well as fluvial sediments are widely distributed to form a flat surface at Luklha near the foreland in the south of the Great Himalayas. 4) The upper limit of vegetation is lower on the west-facing slope than on the east-facing slope. The same differences are observed in the altitude of the temporary snow line and the past end moraine in the Khumbu and Hinku regions. 5) The glaciers on the southand west-facing slopes are retreating faster than those on the north- and east-facing slopes in the recent stage. 6) Though numbers of samples are only two and the more ${ }^{14} \mathrm{C}$ analyses are needed to fix the date of the glacier advances, the ${ }^{14} \mathrm{C}$ age of the Thuklha stage (T-1 substage) is thought to be 16th century and that of the Periche stage 8th century. 7) The change of the glacier area is a marked decrease from the oldest to the recent stage in the Hinku and Hongu regions as compared to that in the Khumbu region, and a large area of the Hongu region is covered by glacial sediments.
Since these observations have been done only in east Nepal, more work is needed to know the local characteristics of geology, topography and climate related to glacial phenomena. The ${ }^{14} \mathrm{C}$ analyses are essential to understand the history of the Himalayan glaciers in relation to that of other regions in the world.

\section{Acknowledgements}

The present author expresses his appreciation to Prof. K. Kigoshi of Gakushuin University for ${ }^{14} \mathrm{C}$ analyses, and to Mr. T. Ohata and Mr. Nima Norb Sherpa for their help in the field observations.

\section{References}

Fushimi, H. (1977): Glaciations in the Khumbu Himal (1). Journal of Japanese Society of Snow and Ice, Vol. 39, Special Issue, 60-67.

Iwata, S. (1976): Late pleistocene and Holocene Moraines in the Sagarmatha (Everest) region, Khumbu Himal. Journal of the Japanese Society of Snow and Ice, Vol. 38, Special Issue, 109-114.

Müller, F. (1959): Eight months of glacier and soil research in the Everest region. The Mountain World, 193-208.

Ohta, Y. et al. (1973): Geology of the Nepal Himalayas. Himalayan Committee of Hokkaido University, Sapporo, Japan.

Schneider, E. et al. (1967): The map of the "Khumbu Himal (Everest)". Ergebnisse des Forshungsunternehmens Nepal Himalaya, Band 1, Lieferung 5 , München.

Schneider, E. et al. (1974): The map of the "Shorong and Hinku". 